\title{
COUNTERFEIT PHARMACEUTICAL DRUGS AS RESEARCH OBJECT IN CRIMINALISTICS
}

\begin{abstract}
Parfilo $I$. $\boldsymbol{V}$.
Counterfeit pharmaceutical drugs are investigated as a subject of a criminal encroachment in the structure of criminalistic characteristics of falsification and circulation of counterfeit drugs. Main channels and sources of receipt of counterfeit pharmaceutical drugs on the Ukranian pharmaceutical market are analyzed. It is proved that structuring of effective method of investigation into examined category of crimes involves carrying out a criminalistic analysis of the criminal encroachment subject and its significance for the structuring of a criminalistic description of these crime. Concept and criminal significant signs of counterfeit pharmaceutical drugs are investigated. It is substantiated that criminalisic feature of the subject of a criminal encroachment other than a criminal law is that it is a consequence of the perceiving and tracing objects of living and inanimate nature, their qualitative and quantitative indices, physico-chemical and consumer properties individualize subject in material world. It is noted that one of the areas of improving the methodology for investigating falsification and circulation of counterfeit pharmaceutical drugs is the study and systematization of data on the subject of a criminal encroachment, identification of regular relationships between him and other elements of the criminalistic description of investigated crime category. The criminalistic classification of counterfeit drugs according to forgery method; pharmacological group; exterior form; a protecting method of packaging or labels; legal regime for pharmaceutical drug treatment is proposed. It has been proved that subject of a criminal encroachment as a structural element of the criminalistic description of falsification and circulation of counterfeit drugs is important for detection, disclosure and investigation on this crime category, as this is an important source of actual information that allows modeling the mechanism of crime committing and provides an opportunity to gather evidence of such criminal activity while investigation. Scientific approaches and suggestions for solving the controversial issues of criminalistic research of counterfeit drugs are formulated and their significance for formulation and implementation of the investigation methodology of this crime category are indicated.

Keywords: counterfeit pharmaceutical drugs, subject of criminal encroachment, circulation of counterfeit drugs, criminalistic description of falsification and circulation of counterfeit drugs.
\end{abstract}

DOI: https://doi.org/10.32353/khrife.2018.16

УДК 34.343.983.7

O. В. Матарикіна, завідувач сектору Харківського НДЕКЦ МВС України E-mail: elmat@ukr.net

\section{ПРОБЛЕМНІ ПИТАННЯ, ЩО ВИНИКАЮТЬ У ХОДІ ОГЛЯДУ МІСЦЯ ПОДІЇ: ВИЯВЛЕННЯ Й ВИЛУЧЕННЯ СЛІДІВ БІОЛОГІЧНОГО ПОХОДЖЕННЯ}

Розглянуто проблемні питання виявлення та вилучення слідів біологічного походження в ході проведення огляду місия подіï. Визначено причини, щзо призводять до зниження якості вилучених слідів. Сформульовано пропозиції щуодо усунення визначених проблем. 
Ключові слова: сліди біологічного походження, огляд місия події, спеиіаліст-біолог, інспектор-криміналіст, якість виявлених і вилучених слідів.

Розроблення нових технічних і тактичних прийомів, методів і засобів у загальній криміналістиці, а також стрімкий розвиток окремої галузі біології - генетики, призводять до зростання кількості інформації біологічного характеру, яку можна отримати в ході кримінального провадження. Про це свідчить і динаміка зростання кількості призначених судових молекулярногенетичних експертиз до Харківського науково-дослідного експертно-криміналістичного центру МВС України (далі - НДЕКЦ). Упродовж останніх трьох років відбулося збільшення призначених експертиз практично вдвічі з 547 до 965 (з 2015 по 2017 р.).

Але зазначена динаміка не $є$ показником збільшення кількості отриманих позитивних результатів і таких, що в подальшому приводять до розкриття злочинів. Так, вилучення предметів: а) якими користувалося багато людей і на яких візуально не спостерігається слідова інформація (наприклад, гроші); б) на яких завідомо не можуть залишитися сліди біологічного походження (наприклад, стріляні гільзи та кулі після дії на них високих температур при пострілі); в) габаритних предметів без видимих слідів біологічного походження, вилучених при огляді місця події (килимові покриття, обшивки автомобілів, простирадла тощо) - призводить до отримання негативних результатів дослідження.

Окремим питанням стоїть і якість вилучених слідів біологічного походження. Біологічна чистота розхідних і пакувальних матеріалів, інструментів і розчинів, за допомогою яких проводиться вилучення слідів, а також суворе дотримання спеціальних вимог і правил учасниками слідчих дій (при роботі зі слідами) виступають тими чинниками, які суттєво впливають на збереження сліду в тому вигляді, у якому він був виявлений, і виключають можливість його забруднення сторонньою ДНК.

Процес реформування органів внутрішніх справ призвів до виникнення низки проблемних питань стосовно організації роботи зі слідами біологічного походження (при проведенні слідчих дій) і можливостей їх подальшого дослідження. На наш погляд, це зумовлено двома основними причинами.

По-перше. Суттєво зменшилась кількість залучень спеціалістів-біологів Експертної служби МВС України до участі в слідчих діях. Зумовлено це, насамперед, тим, що згідно з Інструкцією про порядок залучення працівників органів досудового розслідування поліції та Експертної служби Міністерства внутрішніх справ України як спеціалістів для участі в проведенні огляду місця події (наказ МВС України від 03.11.2015 № 1339) спеціалізована пересувна лабораторія НДЕКЦ може залучатися до участі в проведенні огляду місця події в кримінальному провадженні за клопотанням керівника органу досудового розслідування в разі виникнення об'єктивних обставин, пов'язаних зі вчиненням: 1) убивства або умисного тяжкого тілесного ушкодження, що спричинило смерть потерпілого із застосуванням вогнепальної зброї; 2) розбійного нападу із застосуванням вогнепальної зброї з постраждалими особами; 3 ) згвалтування неповнолітньої чи неповнолітнього, мало- 
літньої чи малолітнього або таке, що спричинило особливо тяжкі наслідки; 4) дорожньо-транспортної пригоди, під час якої загинуло двоє й більше осіб або госпіталізовано до медичних закладів п'ятеро й більше осіб; 5) пожежі, під час якої загинуло двоє й більше осіб або госпіталізовано до медичних закладів п'ятеро й більше осіб; 6) вибуху, загрози вибуху або виявлення саморобних вибухових пристроїв ${ }^{1}$.

По-друге. Існує проблема недостатньої теоретичної підготовки інспекторів-криміналістів (які залучаються до проведення огляду місця події) та відсутності в них необхідних практичних навичок. Створення підрозділів техніко-криміналістичного забезпечення слідчих дій у складі територіальних відділів поліції призвело до відриву інспекторів-криміналістів від навчальної «бази» (регіональних НДЕКЦ) і падіння рівня їх професійної майстерності.

Як правило, в ході огляду слідчий розраховує на активну допомогу спеціаліста-криміналіста у вигляді: застосування необхідних науково-технічних засобів; виявлення й вилучення об'єктів; фіксації ходу та результатів огляду за допомогою технічних засобів; надання пояснень слідчому щодо особливостей і певних властивостей об'єктів (що оглядаються); проведення за допомогою спеціальних засобів попередніх експрес-досліджень; правильного опису виявлених предметів і слідів; консультації щодо правил поводження $з$ ними, пакування й подальшого зберігання; проведення вимірювань; складання планів, креслень тощо ${ }^{2}$.

Вирішення всіх цих завдань покладається на інспекторів-криміналістів, професійна підготовка яких потребує використання нових форматів, технологій і можливостей.

Узагалі в криміналістичній та спеціальній літературі питанню залучення спеціалістів до огляду місця події приділяється не дуже багато уваги. Дослідженню окремих проблем залучення спеціалістів присвятили свої праці такі вчені, як І. В. Гора, В. В. Ковальов, В. Н. Махов, І. В. Пиріг, М. Г. Щербаковський, В. О. Яремчук та ін.

Так, В. О. Яремчук зазначає, що важливі сліди, речові докази, обставини, які мають значення для розкриття злочину, виявляються у випадках, коли спеціаліст особисто бере участь у слідчій дії

В. М. Хрустальов і Р. Ю. Трубіцин, своєю чергою, наголошують узагалі на участі бригади спеціалістів в огляді місця події. Наприклад, на місце тяжких злочинів, що мають значний суспільний резонанс, направляється бригада спеціалістів, а саме: спеціаліст для роботи з традиційними видами слідів; спеціаліст, що спеціалізується на роботі з мікрооб'єктами; спеціаліст-

1 Про затвердження Інструкції про порядок залучення працівників органів досудового розслідування поліції та Експертної служби Міністерства внутрішніх справ України як спеціалістів для участі в проведенні огляду місця події : наказ МВС України від 03.11.2015 № 1339. URL: http://zakon/rada/gov/ua/lavs/show/z1392-15.

2 Яремчук B. О. Проблеми залучення спеціалістів до проведення огляду місця події (організація і тактика). Теорія і практика правознавства. 2015. Вип. 2 (8).

3 Яремчук В. О. Залучення групи спеціалістів при розслідуванні злочинів. Теорія і практика правознавства. 2017. Вип. 2 (12). С. 59-64. 
біолог і спеціаліст за видом вчиненого злочину르. Однак у більшості робіт, як правило, розглядаються загальні питання залучення профільних спеціалістів для роботи з традиційними слідами - слідами рук, взуття, знаряддя злому, транспортних засобів та ін.

Практичні питання техніки і тактики роботи зі слідами біологічного походження частково висвітлюються в роботах таких учених, як Л. О. Барсегянц, М. А. Бронникова, І. В. Лозинський, Т. Ф. Моїсеєва, І. О. Перепечина, В. І. Старовойтова, Т. В. Стегнова, В. В. Томилин, А. К. Туманов. Але ці роботи слід віднести до спеціальної літератури, що часто перешкоджає вільному доступу до них, а змістовне навантаження такої літератури не завжди сприяє чіткому засвоєнню матеріалу слідчими й інспекторами-криміналістами.

У підручниках із криміналістики та програмах підготовки вищих закладів освіти взагалі відсутні цикли з підготовки спеціалістів по роботі зі слідами біологічного походження. Викладений у них матеріал часто поданий інформацією щодо загального поняття про сліди (слідову інформацію), їх класифікацію та характер утворення (трасологію), а якщо й згадується про біологічну природу їх походження, то лише на прикладі слідів крові чи запахових слідів.

Отже, мета статті - розгляд проблемних питань, що виникають при роботі зі слідами біологічного походження в ході проведення слідчих дій, а також пошук і пропонування шляхів їх вирішення.

Робота зі слідами біологічного походження в силу їх специфічності (відсутність стійкої структури, швидка зміна зовнішнього виду під впливом фізичних факторів тощо) потребує спеціальних знань, засобів і методів із їх пошуку, виявлення, фіксації та вилучення. Так, сліди виділення організму людини є не завжди видимі, можуть бути малопомітні в результаті невеликої кількості або дій злочинця з їх знищення ${ }^{2}$. Крім фактичного виявлення слідів, значущу інформацію також можуть нести такі ознаки, як форма, колір, фізичний стан, локалізація на предметах, механізм їх утворення, що не завжди в повному обсязі фіксується при огляді місця події․

Непоодинокі випадки, коли недостатньо підготовленими інспекторамикриміналістами вилучається багато слідів від однієї особи. Причина - відсутність у працівника усвідомлення щодо завдання доказування та значення подальших експертних досліджень слідів біологічного характеру. Наприклад, при виявленні слідів крові вилучається багато предметів (носіїв слідів), що належать в основному потерпілим особам, і не приділяється належна увага іншим слідам.

Виходячи з практичного досвіду працівників Харківського НДЕКЦ інспектори-криміналісти не мають відпрацьованих практичних навичок

${ }^{1}$ Хрусталев В. Н., Трубицын Р. Ю. Участие специалиста-криминалиста в следственных действиях : учеб. пособие. Санкт-Петербург : Питер, 2003. 208 с.

2 Томилин В. В., Барсегяни Л. О., Гладких А. С. Судебно-медицинское исследование вещественных доказательств. Москва : Медицина, 1989. 304 с.

3 Лазебний А. М. Залучення спеціаліста для проведення окремих слідчих дій. Наук. вісник Наи. ун-ту ДПС України. 2014. С. 187-193. 
у пошуку та виявленні різних видів слідів біологічного походження (крові, сперми, слини, волосся, запахових слідів), використанні визначених засобів і методів виявлення слідів, застосуванні необхідного інструментарію й засобів його дезінфекції. Хоча саме перелічені фактори можуть забезпечити якісне вилучення біологічного матеріалу та зменшити ризик контамінації (забруднення біологічного матеріалу сторонньою ДНК).

У ході проведення семінарів, робочих зустрічей і спільних занять працівників органів досудового розслідування Національної поліції та працівників Експертної служби нами було визначено декілька найбільш типових проблемних питань, які виникають при проведенні огляду місця події (у випадках, коли спеціалісти-біологи не залучаються). Як правило, ці питання стосуються: якості проведення огляду; заходів з унеможливлення втрати значущої інформації (характеристики біологічних слідів); дій, спрямованих на збереження вилучених слідів і забезпечення їх придатності для подальшого дослідження.

Найчастіше виникають питання виявлення слідів крові на місці вчинення злочину. На сучасному етапі для пошуку та виявлення таких слідів доцільно використовувати діагностичні експрес-тести «ГемоФан». При контактуванні ймовірного сліду крові та зони індикації на тест-смужці, попередньо зволоженої водою, спостерігається забарвлення індикаторної зони в зелений колір різних відтінків - від світло- до темно-зеленого ${ }^{1}$. Але позитивна реакція вказує лише на можливу присутність крові в досліджуваному об'єкті та потребує подальшого дослідження в лабораторних умовах ${ }^{2}$.

Також для швидкого виявлення слідів крові людини розроблені та широко використовуються в провідних лабораторіях Європи та США спеціальні експрес-тести Seratec HemDirect. Тест заснований на імунохімічній реакції гемоглобіну людини, характеризується високою чутливістю та специфічністю. Завдяки високій специфічності тесту при отриманні позитивного результату можна 3 високою ймовірністю припустити походження крові саме від людини. А завдяки стабільності гемоглобіну тест успішно застосовується при виявленні застарілих слідів крові. Позитивні результати спостерігалися з пробами 31-річної давнини 3.

Зазначені тести не потребують додаткових матеріалів, швидкі в проведенні, тому зручні для використання при огляді місця події. Але ці тести не рекомендується застосовувати при виявленні мікрослідів.

У зв'язку з появою молекулярно-генетичних досліджень, під час яких не використовуються так звані «контрольні змиви» та «контроль предметаносія», виникають питання доцільності їх вилучення при проведенні огляду місця події. Так, у спеціальній літературі рекомендується:

- невеликі предмети зі слідами вилучають у цілому вигляді та упаковують у висушеному стані. У виключних випадках, коли, наприклад, по-

1 SERATEC ® HemDirect. Инструкция по применению/Germany/Rev. 02.2016.

2 Огляд місця події: виявлення та вилучення об'єктів біологічного походження: метод. рекоменд. / С. І. Перлін, С. О. Шевцов, Н. М. Косміна, В. В. Іонова. Харків, 2009. $100 \mathrm{c}$.

SERATEC ® HemDirect. Инструкция по применению/Germany/Rev. 02.2016. 
годні умови унеможливлюють це зробити, предмет упаковують в паперову або картонну упаковки з обов'язковим зазначенням цього факту на упаковці та в протоколі слідчої дії․․

- із предметів-носіїв, які неможливо вилучити в цілому вигляді або якщо предмети мають мистецьку цінність, плями обережно зішкрябають або змивають дистильованою водою. Для цього використовують фрагменти марлевої серветки розмірами, відповідними розміру плями. Для подальшого проведення імунологічної експертизи обов'язкове вилучення та окреме упакування контрольного змиву з предмета-носія (змив із ділянки вільної від нашарування та в безпосередній близькості до нього), а також контроль чистої марлі, аналогічної тій, за допомогою якої було зроблено змив.

Для подальшого проведення молекулярно-генетичного дослідження зазначений контроль не потрібен, але у зв'язку з тим, що рішення про вид подальшого дослідження об'єктів не завжди приймається слідчим безпосередньо при огляді місця події, рекомендується вилучати й окремо упаковувати контрольні змиви, а також здійснювати контроль марлі;

— одяг зі слідами біологічного походження підозрюваної чи потерпілої особи упаковують в окремі упаковки, загортають слідами всередину і перекладають листами чистого білого паперу, щоб уникнути доторкання та перенесення слідів різного походження;

- мікрооб'єкти, що зовні нагадують волосся, вилучаються без застосування металевих інструментів руками в гумових рукавичках і поміщують у паперовий конверт або згортку. Якщо волосся виявлено в слідах засохлої крові, воно вилучається разом із кров'ю або з частинами предмета-носія. Неприпустима фіксація мікрооб'єктів, що зовні нагадують волосся на ізоляційну стрічку та стрічку типу «скотч», у зв'язку з тим, що клейкий шар не дозволяє відокремити мікрооб'єкт без його пошкодження².

Також не рекомендується використовувати для вилучення волосся дактилоскопічні плівки, у зв'язку з тим, що вони мають клейкий шар значної товщини й волосся занурюється в нього, що ускладнює його вилучення та подальше очищення від клейкої речовини.

На підставі проведеного аналізу проблемних питань, із метою підвищення якості вилучення слідів біологічного походження в ході огляду місця події, на нашу думку, необхідно врахувати в роботі слідчих підрозділів і підрозділів інспекторів-криміналістів, що входять до складу Головних управлінь національної поліції в областях, таке:

- залучати спеціалістів-біологів регіональних НДЕКЦ до огляду місця події за фактами вчинення тяжких злочинів;

— вирішити проблему недостатньої теоретичної підготовки інспекторівкриміналістів і відсутності в них необхідних практичних навичок шляхом організації систематичних занять із запрошенням спеціалістів-біологів регіональних НДЕКЦ;

1 Огляд місця події: виявлення та вилучення об’єктів біологічного походження: метод. рекоменд.

2 Огляд місця події: виявлення та вилучення об'єктів біологічного походження: метод. рекоменд. 
— вирішити для підрозділів слідства й інспекторів-криміналістів питання з ліквідації інформаційного «голоду» за напрямом «пошук - вилучення упакування слідів біологічного походження» шляхом забезпечення необхідною літературою (посібниками, довідниками, науково-методичними рекомендаціями, інформаційними листами тощо).

Запропонований комплексний підхід до вдосконалення організації професійної підготовки працівників слідчих підрозділів і підрозділів інспекторів-криміналістів, на наш погляд, сприятиме підвищенню якості виявлення й вилучення слідової інформації біологічного характеру, що безумовно сприятиме отриманню позитивних результатів на стадії досудового розслідування кримінальних правопорушень.

\section{ПРОБЛЕМНЫЕ ВОПРОСЫ, ВОЗНИКАЮЩИЕ В ХОДЕ ОСМОТРА МЕСТА ПРОИСШЕСТВИЯ: ВЫЯВЛЕНИЕ И ИЗЪЯТИЕ СЛЕДОВ БИОЛОГИЧЕСКОГО ПРОИСХОЖДЕНИЯ}

\section{Матарыкина $\boldsymbol{E}$. В.}

Разработка новых технических и тактических приемов, методов и средств в общей криминалистике, а также стремительное развитие генетики приводят к росту количества информации биологического характера, которую можно получить в ходе проведения осмотра места происшествия. Увеличение количества назначенных экспертиз не всегда приводит к получению положительных результатов. Это зависит от полноты и качества изъятых следов. Уменьшение количества привлечений специалистов-биологов Экспертной службы МВД Украины кучастию в следственных действиях, недостаточная теоретическая и практическая подготовка инспекторов-криминалистов, которые привлекаются к проведению осмотра места происшествия, - это факторы, влияюшче на полноту и качество изъятой биологической информачии. Работа со следами биологического происхождения из-за их специифичности нуждается в специальных знаниях. Недостаточность доступной методической литературы по технике и тактике работы со следами биологического происхождения, отсутствие в учебниках по криминалистике и в программах подготовки высших учебных заведений информации, касающейся поиска, выявления и правил изъятия таких следов, приводит к возникновению ряда вопросов относительно качества проведения осмотра, мероприятий по предотвращению потери значащей информации, действий, направленных на сохранение изъятых следов и обеспечение их пригодности для дальнейтего исследования. Проанализировав основные проблемные вопросы, которые возникают при работе с биологическими следами в ходе осмотра места происшествия, предложены следующие пути их решения: привлекать специилистов-биологов региональных иентров к осмотру места происшествия за фактами совершения тяжких преступлений; решить проблему недостаточной теоретической подготовки инспекторов-криминалистов и отсутствия у них необходимых практических навыков путем организации систематических занятий с приглашением специалистов-биологов региональных иентров; обеспечить необходимой литературой подразделения следствия и инспекторовкриминалистов по направлению «поиск - изъятие - упаковка следов биологического происхождения»; внести в программы подготовки следователей и инспекторовкриминалистов высших учебных заведений ичиль по работе со следами биологического происхождения. 
Ключевые слова: следы биологического происхождения, осмотр места происиествия, специалист-биолог, инспектор-криминалист, качество выявленных и изъятых следов.

\title{
PROBLEMATIC ISSUES ARISING WHILE CRIME SCENE SURVEY: DETECTION AND SEIZURE OF BIOLOGICAL ORIGIN TRACES
}

\begin{abstract}
Matarykina $\boldsymbol{O} . \boldsymbol{V}$.
Development of new technical and tactical methods, techniques and means in general criminalistics, as well as rapid development of genetics, leads to an increase in biological information content that can be obtained during crime scene investigation. Increase in the number of appointed examinations does not always lead to positive results. It depends on completeness and quality of exempt traces. Reducing the number of biologists involvement of Expert service of the Ministry of Internal Affairs of Ukraine to participate in investigative actions, insufficient theoretical and practical training of criminalist inspectors involved in crime scene survey are factors that affect completeness and quality of the extracted biological information. Work with traces of biological origin requires special knowledge due to their specificity. The lack of accessible methodological literature on techniques and tactics of work with traces of biological origin, the absence of information in criminalistics textbooks and in higher education institution training programs on search, detection and seizure rules of such tracks leads to the contraction of number questions regarding the quality of the crime scene survey, measures to prevent loss of important information, actions aimed at preserving exempt traces and ensuring their appropriateness for further research. After analyzing main issues that arise while working with biological tracks during crime scene survey, the following ways of solving them are proposed: involve biologists of regional centers in reviewing the crime scene survey according to facts of committing grave crimes; to solve the problem of insufficient theoretical training of criminalist inspectors and absence of necessary practical skills by organizing systematic classes with invitation of biologists from regional centers; provide the necessary literature for investigation departments and criminalist inspectors to the direction "search-seizurepacking of traces of biological origin"; introduce cycles on work with tracks of biological origin in trainings programs of investigators and criminalist inspectors of higher educational establishments.
\end{abstract}

Keywords: traces of biological origin, crime scene investigation, specialist biologist, forensic scientist, quality of detected and exempt traces. 